\title{
Effects of selenium-rich yeast supplementation on the plasma progesterone levels of postpartum dairy cows
}

\author{
Hachiro Kamada ${ }^{1,2, *}$
}

* Corresponding Author: Hachiro Kamada Tel: +81-29-838-8658, Fax: +81-29-838-8672, kama8@affrc.go.jp

' Dairy cattle Group, Hokkaido Agricultural Research Center NARO, Sapporo, Hokkaido 062-8555, Japan

${ }^{2}$ Animal Reproduction Unit, Institute of Livestock and Grassland Science NARO, Tsukuba, Ibaraki 305-0901 Japan

Submitted May 10, 2016; Revised Jul 3, 2016: Accepted Aug 3, 2016
Objective: The effects of the pre- and postpartum supplementation of cows with Se on their plasma P4 concentrations after calving were investigated.

Methods: Thirty-four Holstein cows were used to investigate the effects of dietary selenium supplementation on the postpartum recovery of the luteal function in cows. Selenium-rich yeast (containing $300 \mathrm{ppm}$ selenium) was mixed with total mixed ration fed to 17 pregnant cows from 30 days before they were due to calve ( $10 \mathrm{~g}$ yeast daily) to 100 days after calving ( $20 \mathrm{~g}$ yeast daily). The control cows $(\mathrm{n}=17)$ were fed the same amount of ordinary yeast. The cows' plasma progesterone concentrations were determined every two days using an enzyme immunoassay after calving.

Results: Feed intake (total digestive nutrient, crude protein), milk production, body weight and the biochemical properties of blood plasma did not differ between the two groups; however, the plasma selenium concentrations of the supplemented animals were significantly greater than those of the controls at and after calving. The postpartum plasma progesterone concentrations of the selenium-yeast-supplemented group increased earlier than those of the control group. Moreover, during the estrus cycle after the 3rd ovulation or ovulation with estrus between 60 to 80 days after calving, the selenium-supplemented cows exhibited greater progesterone concentrations than the control cows.

Conclusion: Selenium supplementation promotes the postpartum progesterone production of cows.

Keywords: Cow; Postpartum Progesterone; Reproduction; Selenium

\section{INTRODUCTION}

In recent years, dairy cow fertility has been progressively worsening around the world, so the improvement of conception rates has become an important problem. Although the causes of the abovementioned worsening of dairy cow fertility are considered to be multifactorial, recent studies have focused on elevating corpus luteum (CL) function as a way of solving the problem. Many researchers have reported the importance of $C L$ function for reproduction. For example, reduced plasma progesterone ( $\mathrm{P} 4)$ levels during the growth of ovulatory follicles was found to be associated with a decreased conception rate [1], and low embryo survival during early gestation was demonstrated to be associated with a low plasma P4 concentration [2]. It was also reported that the postpartum plasma $\mathrm{P} 4$ level is positively correlated with the conception rate [3] and that endogenous $\mathrm{P} 4$ before insemination influences embryo recovery [4]. These results suggest that postpartum CL function is one of the key factors affecting reproductive performance. Although basic hormonal regulation must be normalized to allow the postpartum recovery of CL function, nutrient factors are also known to have an effect on it. Previous studies have demonstrated that the consumption of various supplements results in increased plasma P4 levels. For example, Spicer et al [5] and other researchers [6,7] have shown that sup- 
plementing cows with fats increased their plasma P4 levels. Whilst the mechanism responsible for this effect is likely to be at least partially related to energy supply, it is also considered to involve the inhibition of prostaglandin synthesis by fat-derived linoleic acid [8]. Moreover, micronutrients are also considered to contribute to luteal function, e.g., Kawashima et al [9] reported that $\beta$-carotene supply supports the postpartum reestablishment of luteal activity in dairy cows, and Arellano-Rodriguez et al [10] showed that $\beta$-carotene enhances ovarian function and $\mathrm{P} 4$ synthesis in goats.

In this study, we focused on selenium (Se), which is an essential micro-mineral for animals and is known to contribute to their animal reproductive performance. For example, the prepartum injection of Se reduced the incidence of metritis and ovarian cysts as well as the interval from calving to conception in lactating dairy cows [11-12]. In addition, positive associations have been found between increased prepartum blood Se concentrations and decreased postpartum incidence of mastitis, ovarian cysts, and silent estrus [13], and Holstein heifers that received injections of Se and vitamin E 4 and 2 weeks before expected calving exhibited fewer open days and a low number of services per conception [14]. However, the mechanisms responsible for these positive effects of Se on reproduction and the target tissue of Se are not clear. Although some Se-containing enzymes have been identified [15], the relationships between these enzymes and the reproductive function of animals are still under investigation.

The objective of this experiment was to determine the effects of the pre- and postpartum supplementation of cows with Se on their plasma $\mathrm{P} 4$ concentrations after calving.

\section{MATERIALS AND METHODS}

\section{Animal care}

This study was approved by the Animal Care and Use Committee of Hokkaido Agriculture Research Center NARO.

\section{Experimental design}

Thirty-four pregnant Holstein cows weighing $686.5 \pm 49.6 \mathrm{~kg}$ (at 4 weeks before they were due to calve) were assigned to experimental diets based on their body weight (BW) and expected milk yield. Their mean parity value was $1.9 \pm 1.03$. The experiment period was from 30 days prepartum to the 100th day of the postpartum period. Total mixed ration (TMR), which consisted of alfalfa pellets, flaked soybean, orchard grass silage, corn silage, concentrate and beet pulp pellets, was administered twice daily. The representative composition of TMR and the amount supplied are shown in Table 1. The amount of food supplied to each cow was adjusted every week based on their milk production, BW, parity, and lactation stage according to the NRC requirements [16]. Body weight was measured before feeding in the morning every week. The mean Se concentration of the basal TMR was
Table 1. Representative composition of TMR (body weight $696 \mathrm{~kg}$, milk production $49.2 \mathrm{~kg}, 60$ days after delivery, Parity 2)

\begin{tabular}{lc}
\hline Diet composition (dry matter) & \\
\hline Alfalfa pellet $(\mathrm{kg})$ & 1.59 \\
Flaked soybean $(\mathrm{kg})$ & 1.53 \\
Orchard grass silage $(\mathrm{kg})$ & 6.80 \\
Corn silage $(\mathrm{kg})$ & 7.33 \\
Concentrate) $(\mathrm{kg})$ & 12.21 \\
Beet pulp pellet $(\mathrm{kg})$ & 1.70 \\
Orchard hay $(\mathrm{kg})$ & 0.89 \\
Calculated TDN $(\mathrm{kg})$ & 22.67 \\
Determined CP $(\mathrm{kg})$ & 5.05 \\
Selenium Conc. $(\mathrm{ppm})$ & 0.04 \\
\hline
\end{tabular}

TMR, total mixed ration; TDN, total digestive nutrient; $C P$, crude protein; DM, dry matter. ${ }^{1)}$ Mixture of $40 \%$ commercial diet (Meiji, Japan), 18\% oats, 18\% flaked wheat, $14 \%$ flaked corn, 10\% flaked soybean cake and 0.8\% calcium carbonate; TDN/DM: $80.0 \%$, CP/DM: $18.9 \%)$.

$0.04 \mathrm{ppm}$. Dry matter (DM) intake was measured on 3 days each week. Cows had access to water ad libitum. Selenium yeast (Bussan-Biotech, Tokyo, Japan) containing 300 ppm Se was added to the cows' (primiparous: $\mathrm{n}=7$, multiparous: $\mathrm{n}=$ 10) diets at doses of $10 \mathrm{~g}$ per day and $20 \mathrm{~g}$ per day in pre- and postpartum periods, respectively. This amount is about $0.1 \%$ of whole diet. When selenium-rich yeast is mixed with the diet at the concentration of $0.1 \%$, the final concentration of selenium in diet is $0.3 \mathrm{ppm}$, which is selenium requirement of NRC. The control group (primiparous: $\mathrm{n}=8$, multiparous: $\mathrm{n}$ = 9) was fed the same amount of ordinary yeast without Se. Blood sampling $(10 \mathrm{~mL})$ from the jugular vein was carried out using heparinized tubes before feeding in the morning every two days after calving. After being centrifuged $(1,000 \times \mathrm{g}$, $20 \mathrm{~min}, 4^{\circ} \mathrm{C}$ ), the plasma samples were stored at $-20^{\circ} \mathrm{C}$ until the analysis. One of our interests in the present study was the function of CL formed during 60 to 80 days after calving, when farmers usually start artificial insemination (AI), therefore AI was not performed during this period in order to eliminate the effect of pregnancy (AI was carried out for animals at their fourth ovulation after calving, or at their first ovulation beyond 80 days after calving in the case of no fourth ovulation in the experimental period.). When the $\mathrm{P} 4$ production of all CL was calculated for each estrous cycle, the sampling day preceding the day on which the plasma P4 concentration exceeded $1 \mathrm{ng} /$ $\mathrm{mL}$ at the beginning of the luteal phase was defined as Day 0 . When the estrus was observed, the estrus day was defined as Day 0.

\section{Analytical methods}

Plasma P4 concentrations were measured using an enzyme immunoassay kit (NEOGEN, Lexington, KY, USA). The samples were extracted with diethylether (WAKO, Osaka, Japan). And all assays were performed in duplicate. The intra- and interassay co-efficients of variation were $9.81 \%$ and $12.54 \%$, respectively. 
The plasma Se concentrations were measured using a graphite furnace atomic absorption spectrophotometer with Zeeman correction (Z-5000; Hitachi High-Technologies, Tokyo, Japan). Biochemical blood plasma parameters (glutamic oxaloacetic transaminase [GOT], lactate dehydrogenase [LDH], alkaline phosphatase, total protein, albumin, blood urea nitrogen [BUN], blood glucose, cholesterol, non-esterified fatty acid [NEFA], triglyceride, inorganic phosphorus, ketone body $(\mathrm{KB})$, iron $(\mathrm{Fe})$, calcium $(\mathrm{Ca})$, sodium $(\mathrm{Na})$, chlorine $(\mathrm{Cl})$, magnesium $(\mathrm{Mg})$, potassium $[\mathrm{K}]$ ) were determined using Hitachi Automatic Analyzer 7250 (Hitachi High-Technologies, Tokyo, Japan).

Samples of the remaining feed and TMR were dried at $60^{\circ} \mathrm{C}$ for $48 \mathrm{~h}$ in a drying machine and had their nitrogen and acid detergent fiber $(\mathrm{ADF})$ contents analyzed. Total digestive nutrient (TDN) was calculated using the following equations [17]: TDN $=89.89-0.752 \times \mathrm{ADF}$ (corn silage), $\mathrm{TDN}=87.57-0.737 \times \mathrm{ADF}$ (grass silage). ADF was determined according to the method of Van Soest [18]. Crude protein (CP) values were calculated based on nitrogen content, which were measured using the Kjeldahl method.

\section{Statistical analysis}

The data regarding the cows' DM intake, BW, TDN intake, CP intake, plasma biochemical parameters, and postpartum plasma Se and $\mathrm{P} 4$ concentrations were analyzed using the mixed method procedure. Multiple comparisons analysis of mean values was performed using the Bonferroni method. The area under the curve (AUC) values of the plasma $\mathrm{P} 4$ concentration in each estrus cycle and milk production during the first 100 days postpartum were subjected to analysis of variance using the general linear models procedure [19]. Results were considered significant at $\mathrm{p}<0.05$.

\section{RESULTS}

\section{Nutritional condition}

It is known that the energy and protein intake affect reproductive performance $[5,6,20]$, so, in order to accurately assess the effect of Se on luteal function, the amount of feed supplied to the cows was controlled to meet their nutritional requirements of dairy cows [16]. Consequently, the DM, TDN, and CP intakes of Se-supplemented and control cows did not differ (Figure 1 and Table 2). Also, the postpartum BW changes and the amount of milk yield were not different between the two treatments (Figurses 1 and 2). On average, the primiparous and multiparous cows produced 8,600 $\mathrm{kg}$ and 10,900 $\mathrm{kg}$ of milk during 305 days, respectively. The cows' plasma Se concentrations gradually increased during the experiment period; however, the Se-supplemented cows displayed greater plasma Se concentrations at all time-points after treatment initiation $(\mathrm{p}<0.0001)$ (Figure 3$)$. The value of supplemented animals at 30 days after calving was mostly sufficient $(>70 \mathrm{ppb})$, while that of the control cows was
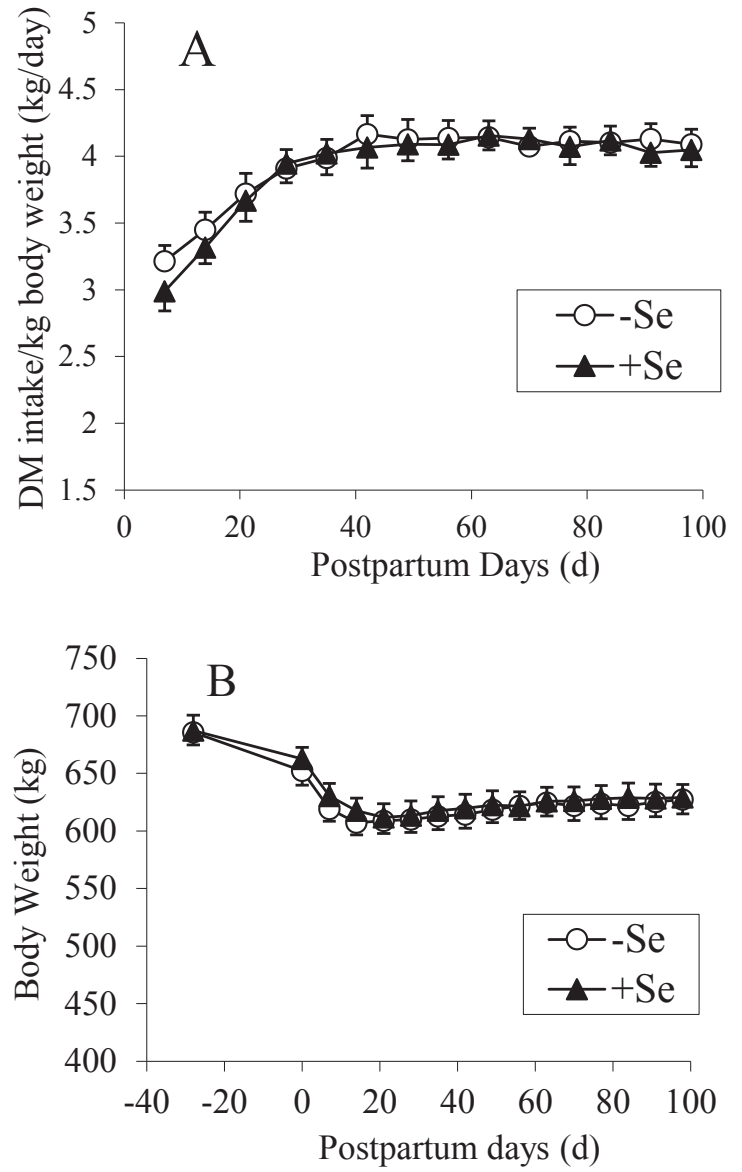

Figure 1. Changes of (A) dry matter (DM) intake $(\mathrm{kg})$, and (B) body weight $(\mathrm{kg})$ (mean \pm standard error of the mean; -Se: $n=17,+$ Se: $n=17$ ). DM intake was measured on 3 days each week. Samples of the remaining feed and TMR were dried at $60^{\circ} \mathrm{C}$ for $48 \mathrm{~h}$ in a drying machine. Body weight was measured before feeding in the morning every week.

marginal or deficient $(<40 \mathrm{ppb})$ [21] until 60 days after calving. Large inter-group differences were not observed in any of the plasma biochemical parameters (Table 3). The plasma LDH activity differed significantly $(\mathrm{p}=0.0068)$ at a single point (at calving); however, no such differences were observed during the rest of the experiment. These results showed that except for their plasma Se levels the cows in the two treatments were in the same nutritional condition.

\section{Postpartum plasma progesterone concentration}

The postpartum plasma $\mathrm{P} 4$ concentrations of the Se-supplemented between $8 \mathrm{~d}$ and $50 \mathrm{~d}$ cows were significantly greater $(\mathrm{p}<0.0001)$

Table 2. TDN intake $(\mathrm{kg})$ and $\mathrm{CP}$ intake $(\mathrm{kg})$ at 30, 60, and 90 days after calving

\begin{tabular}{lcrrr}
\hline & Se & \multicolumn{1}{c}{$30 \mathrm{~d}$} & \multicolumn{1}{c}{$60 \mathrm{~d}$} & \multicolumn{1}{c}{$90 \mathrm{~d}$} \\
\hline TDN intake $(\mathrm{kg})$ & - & $15.74 \pm 0.70$ & $17.21 \pm 0.61$ & $17.23 \pm 0.60$ \\
& + & $15.88 \pm 0.73$ & $17.17 \pm 0.57$ & $17.10 \pm 0.52$ \\
CP intake $(\mathrm{kg})$ & - & $3.85 \pm 0.19$ & $4.08 \pm 0.16$ & $4.03 \pm 0.16$ \\
& + & $3.84 \pm 0.17$ & $4.07 \pm 0.13$ & $3.97 \pm 0.13$ \\
\hline
\end{tabular}

TDN, total digestive nutrient; $C P$, crude protein. 


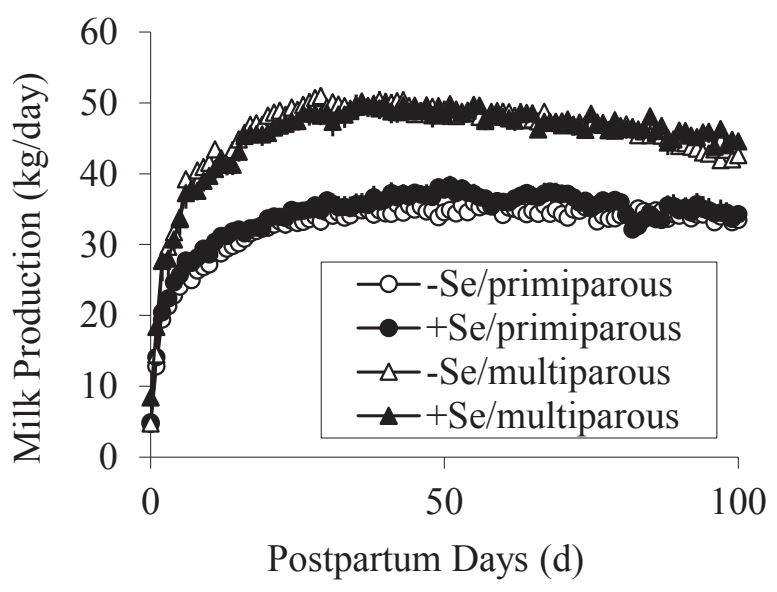

Figure 2. Profile of the milk production $(\mathrm{kg} / \mathrm{d})$ (mean \pm standard error of the mean) of prrimiparous (-Se: $n=8,+$ Se: $n=7$ ) and multiparous (-Se: $n=9$, + Se: $n=10$ ) cows between 0 to 100 days after calving. Data of milk production was collected every days at milking parlor.

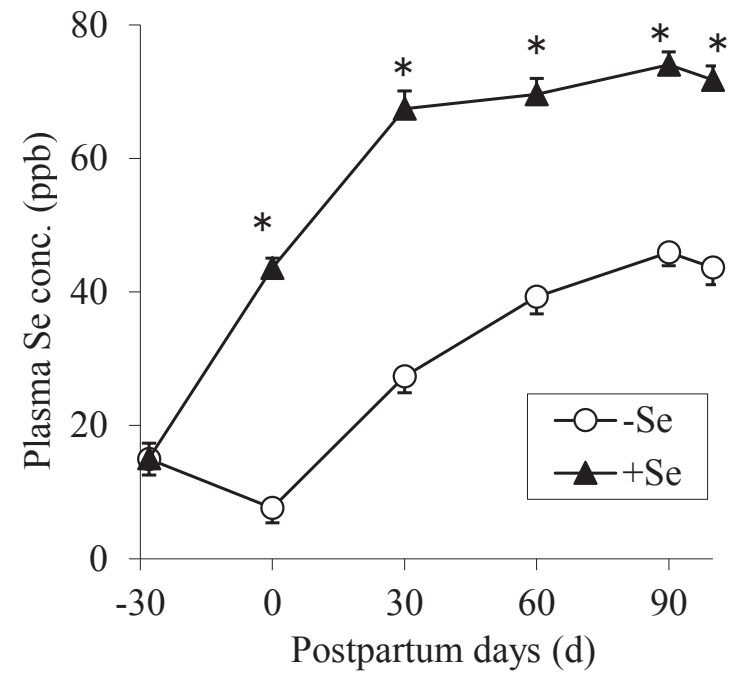

Figure 3. Changes in the plasma Se concentration $(\mathrm{ppb})$ relative to parturition (mean \pm standard error of the mean; -Se: $n=17,+S e: n=17)$. Blood sampling from the jugular vein was carried out in the morning on $-30 \mathrm{~d}, 0 \mathrm{~d}, 30 \mathrm{~d}, 60 \mathrm{~d}, 90 \mathrm{~d}$, and $100 \mathrm{~d}$ after delivery. The Se concentrations of blood plasma was analyzed using an atomic absorption spectrophotometer. Significant difference according to the Bonferroni method was defined as a $p$ value of $<0.05\left(^{*}\right)$.

Table 3. Effects of Se supplementation on plasma biochemical parameters

\begin{tabular}{|c|c|c|c|c|c|c|c|c|}
\hline \multirow{2}{*}{ Item } & \multirow{2}{*}{ Se } & \multicolumn{7}{|c|}{ Time after delivery } \\
\hline & & $-28 d$ & $0 \mathrm{~d}$ & $14 \mathrm{~d}$ & $30 \mathrm{~d}$ & $60 \mathrm{~d}$ & $90 \mathrm{~d}$ & $100 \mathrm{~d}$ \\
\hline \multirow[t]{2}{*}{ GOT (IU/L) } & - & $61.9 \pm 3.4$ & $71.9 \pm 6.2$ & $85.8 \pm 5.3$ & $73.3 \pm 3.0$ & $76.1 \pm 3.9$ & $77.3 \pm 4.6$ & $75.7 \pm 4.1$ \\
\hline & + & $59.7 \pm 4.2$ & $58.6 \pm 2.1$ & $85.6 \pm 3.8$ & $73.2 \pm 3.2$ & $73.9 \pm 3.2$ & $76.9 \pm 3.5$ & $74.5 \pm 3.0$ \\
\hline \multirow[t]{2}{*}{ LDH (IU/L) } & - & $773 \pm 32$ & $905 \pm 83 a$ & $888 \pm 33$ & $822 \pm 24$ & $795 \pm 22$ & $814 \pm 27$ & $810 \pm 21$ \\
\hline & + & $739 \pm 40$ & $768 \pm 29 b$ & $903 \pm 30$ & $822 \pm 24$ & $820 \pm 25$ & $839 \pm 22$ & $835 \pm 19$ \\
\hline \multirow[t]{2}{*}{$\mathrm{ALB}(\mathrm{g} / \mathrm{dL})$} & - & $4.17 \pm 0.04$ & $4.11 \pm 0.06$ & $4.22 \pm 0.06$ & $4.37 \pm 0.08$ & $4.40 \pm 0.08$ & $4.39 \pm 0.06$ & $4.43 \pm 0.06$ \\
\hline & + & $4.10 \pm 0.05$ & $4.00 \pm 0.07$ & $4.17 \pm 0.06$ & $4.28 \pm 0.05$ & $4.26 \pm 0.05$ & $4.34 \pm 0.07$ & $4.26 \pm 0.05$ \\
\hline \multirow[t]{2}{*}{ BUN (mg/dL) } & - & $14.0 \pm 1.0$ & $12.4 \pm 0.6$ & $11.5 \pm 0.7$ & $14.2 \pm 0.6$ & $14.7 \pm 0.5$ & $14.2 \pm 0.8$ & $13.8 \pm 0.5$ \\
\hline & + & $13.1 \pm 0.7$ & $11.0 \pm 0.7$ & $12.2 \pm 0.7$ & $14.1 \pm 0.7$ & $14.1 \pm 0.4$ & $14.5 \pm 0.7$ & $14.2 \pm 0.5$ \\
\hline \multirow[t]{2}{*}{$\mathrm{GLU}(\mathrm{mg} / \mathrm{dL})$} & - & $67.1 \pm 1.4$ & $101.5 \pm 7.0$ & $66.1 \pm 2.0$ & $68.3 \pm 1.0$ & $70.7 \pm 1.2$ & $69.0 \pm 1.3$ & $69.9 \pm 1.1$ \\
\hline & + & $67.4 \pm 1.1$ & $107.0 \pm 6.1$ & $63.6 \pm 2.4$ & $67.0 \pm 1.7$ & $69.0 \pm 1.5$ & $70.9 \pm 1.5$ & $68.9 \pm 0.7$ \\
\hline \multirow[t]{2}{*}{ Cho (mg/dL) } & - & $110 \pm 5$ & $76 \pm 3$ & $127 \pm 5$ & $191 \pm 8$ & $243 \pm 10$ & $242 \pm 11$ & $251 \pm 13$ \\
\hline & + & $101 \pm 3$ & $65 \pm 3$ & $109 \pm 6$ & $167 \pm 7$ & $218 \pm 10$ & $229 \pm 9$ & $228 \pm 9$ \\
\hline \multirow[t]{2}{*}{ NEFA $(\mu \mathrm{Eq} / \mathrm{L})$} & - & $257 \pm 35$ & $587 \pm 54$ & $782 \pm 108$ & $353 \pm 42$ & $251 \pm 57$ & $152 \pm 11$ & $169 \pm 14$ \\
\hline & + & $213 \pm 32$ & $575 \pm 55$ & $629 \pm 72$ & $387 \pm 42$ & $193 \pm 21$ & $149 \pm 13$ & $232 \pm 74$ \\
\hline \multirow[t]{2}{*}{$\mathrm{KB}(\mu \mathrm{M})$} & - & $412 \pm 27$ & $527 \pm 39$ & $876 \pm 71$ & $663 \pm 46$ & $608 \pm 55$ & $527 \pm 45$ & $636 \pm 49$ \\
\hline & + & $422 \pm 29$ & $476 \pm 26$ & $1213 \pm 222$ & $717 \pm 52$ & $646 \pm 106$ & $555 \pm 40$ & $575 \pm 46$ \\
\hline \multirow[t]{2}{*}{$\mathrm{Ca}(\mathrm{mg} / \mathrm{dL})$} & - & $10.1 \pm 0.1$ & $8.8 \pm 0.2$ & $9.9 \pm 0.2$ & $10.3 \pm 0.1$ & $10.4 \pm 0.1$ & $10.5 \pm 0.1$ & $10.6 \pm 0.1$ \\
\hline & + & $10.0 \pm 0.1$ & $8.9 \pm 0.2$ & $10.2 \pm 0.2$ & $10.4 \pm 0.2$ & $10.5 \pm 0.1$ & $10.5 \pm 0.1$ & $10.4 \pm 0.1$ \\
\hline \multirow[t]{2}{*}{$\mathrm{Fe}(\mu \mathrm{g} / \mathrm{dL})$} & - & $159 \pm 8$ & $91 \pm 9$ & $121 \pm 11$ & $130 \pm 7$ & $141 \pm 5$ & $139 \pm 6$ & $131 \pm 10$ \\
\hline & + & $147 \pm 7$ & $98 \pm 7$ & $119 \pm 8$ & $133 \pm 7$ & $124 \pm 5$ & $135 \pm 6$ & $128 \pm 8$ \\
\hline \multirow[t]{2}{*}{$\mathrm{Mg}(\mathrm{mg} / \mathrm{dL})$} & - & $2.28 \pm 0.06$ & $2.32 \pm 0.06$ & $2.57 \pm 0.05$ & $2.69 \pm 0.06$ & $2.62 \pm 0.06$ & $2.56 \pm 0.04$ & $2.58 \pm 0.08$ \\
\hline & + & $2.26 \pm 0.08$ & $2.28 \pm 0.06$ & $2.55 \pm 0.05$ & $2.67 \pm 0.05$ & $2.48 \pm 0.04$ & $2.54 \pm 0.04$ & $2.50 \pm 0.04$ \\
\hline \multirow[t]{2}{*}{$\mathrm{Na}(\mathrm{mEq} / \mathrm{L})$} & - & $142.0 \pm 0.6$ & $147.9 \pm 0.6$ & $141.5 \pm 0.5$ & $140.9 \pm 0.5$ & $140.7 \pm 0.8$ & $140.3 \pm 0.6$ & $139.9 \pm 0.7$ \\
\hline & + & $141.3 \pm 0.7$ & $147.2 \pm 1.0$ & $141.4 \pm 0.5$ & $140.2 \pm 0.7$ & $140.2 \pm 0.6$ & $140.1 \pm 0.7$ & $140.1 \pm 0.8$ \\
\hline \multirow[t]{2}{*}{$\mathrm{Cl}(\mathrm{mEq} / \mathrm{L})$} & - & $102.4 \pm 0.6$ & $106.7 \pm 0.7$ & $101.2 \pm 0.9$ & $100.6 \pm 0.7$ & $101.3 \pm 0.9$ & $100.8 \pm 0.9$ & $100.8 \pm 1.0$ \\
\hline & + & $102.5 \pm 0.7$ & $107.5 \pm 1.0$ & $101.7 \pm 0.5$ & $100.8 \pm 0.6$ & $100.3 \pm 0.7$ & $101.0 \pm 0.7$ & $100.1 \pm 0.6$ \\
\hline \multirow[t]{2}{*}{$\mathrm{K}(\mathrm{mEq} / \mathrm{L})$} & - & $3.78 \pm 0.12$ & $3.75 \pm 0.07$ & $3.93 \pm 0.10$ & $4.02 \pm 0.09$ & $3.91 \pm 0.14$ & $4.02 \pm 0.07$ & $3.86 \pm 0.09$ \\
\hline & + & $3.68 \pm 0.09$ & $3.92 \pm 0.07$ & $3.88 \pm 0.07$ & $3.90 \pm 0.08$ & $4.00 \pm 0.08$ & $3.87 \pm 0.06$ & $3.93 \pm 0.06$ \\
\hline
\end{tabular}

GOT, glutamic oxaloacetic transaminase; LDH, lactate dehydrogenase; ALB, albumin; BUN, blood urea nitrogen; GLU, glucose; Cho, cholesterol; NEFA, non-esterified fatty acid; KB, ketone body.

Data with different superscript are significant different according to the Bonferroni method $(p<0.05)$. 
than those of the control cows at 32 and 34 day after calving $(\mathrm{p}=0.0003,0.0004)$, and tended to be greater at 38 day after calving $(p=0.0030)$ (Figure 4$)$. These results showed that the postpartum plasma $\mathrm{P} 4$ concentration was elevated earlier by Se supplementation.

The effect of Se on the plasma P4 concentration was assessed at each estrus cycle (Figure 5). The mean P4 AUC for all of the CL observed during the experimental period (Figure 5A) were slightly increased by Se supplementation, but the changes were not statistically significant $(\mathrm{p}=0.50694)$. However, the $\mathrm{P} 4 \mathrm{AUC}$ in the luteal phase after the 3 rd ovulation with estrus, and the AUC for the CL formed after ovulation with estrus between 60 to 80 days after calving (the timing at which farmers generally attempt AI of cows) were significantly greater in the Se-supplemented cows than in the control (Figure 5B: $\mathrm{p}=$ 0.04217, 5C: $\mathrm{p}=0.00672$ ).

\section{DISCUSSION}

Peroxide production is expected during P4 biosynthesis, because a side-chain-cleaving enzyme (P450) that is involved in the metabolism of cholesterol ( $\mathrm{P} 4$ precursor) uses molecular oxygen several times and frequently produces radicals [22]. Selenium is an antioxidant and is an essential component of glutathione peroxidase (GPX) [23], phospholipid hydroperoxide glutathione peroxidase [24] and thioredoxin reductase. In addition, a previous experiment using ${ }^{75} \mathrm{Se}[25]$ showed that CL preferentially incorporates Se. From this information, we hypothesized that Se degrades peroxides in $\mathrm{CL}$, which contributes to maintaining their function. We have reported that the addition of Se to cultured bovine luteal cells increased the P4 concentration of

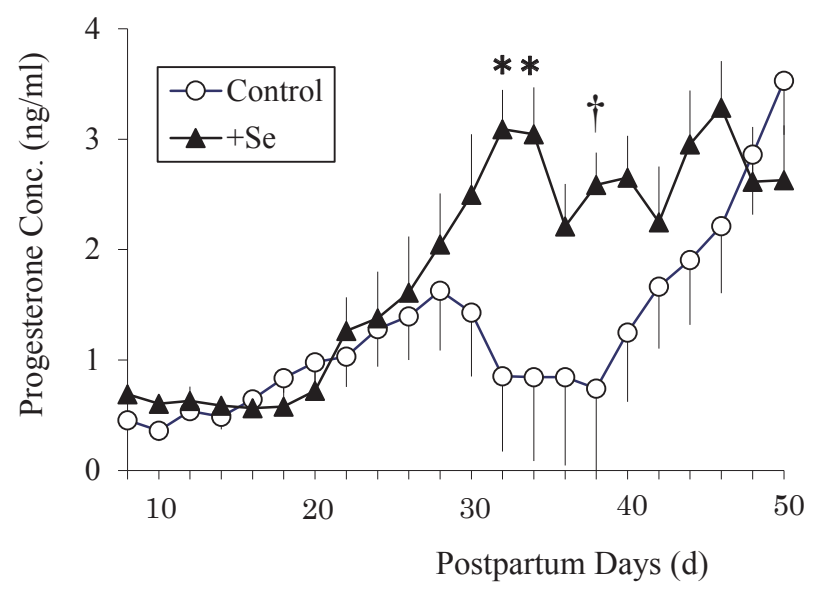

Figure 4. Effect of Se yeast supplementation on the plasma P4 concentration during the first 100 postpartum days (mean \pm standard error of the mean; -Se: $n=17$, +Se: $n$ $=17$ ). Blood sampling from the jugular vein was carried out in the morning every two days. Plasma P4 concentrations were measured using an enzyme immunoassay kit after diethylether extraction. All assays were performed in duplicate. Significant difference according to the Bonferroni method was defined as a p value of $<0.05\left(^{*}\right)$ and $<0.07(\dagger)$.
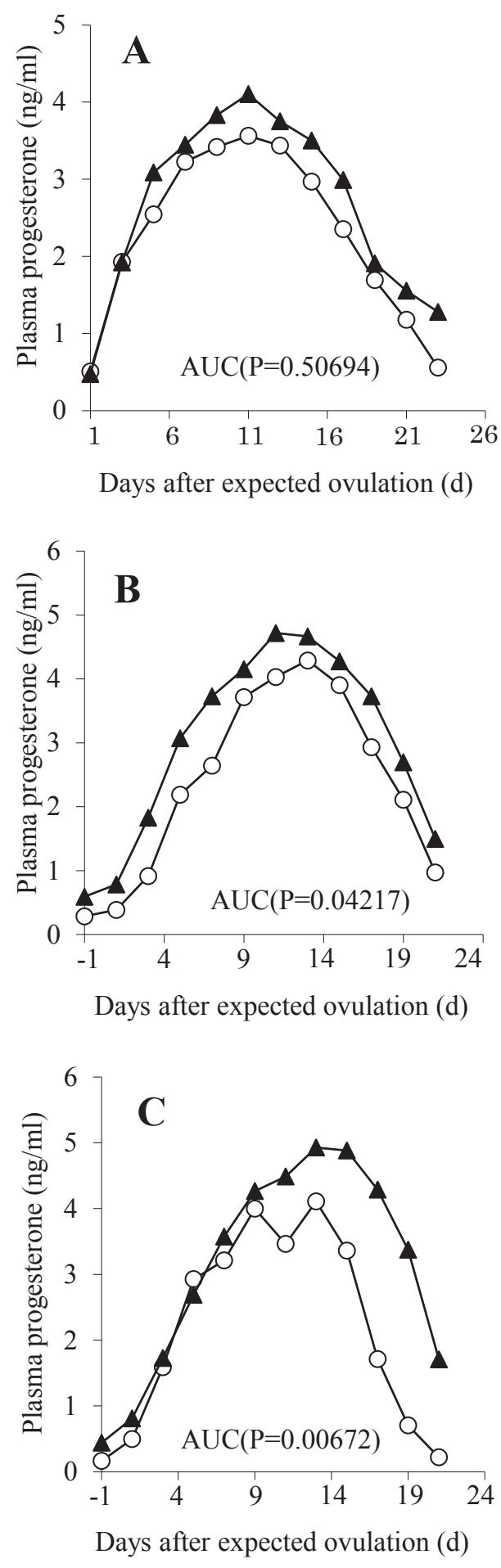

Figure 5. Effect of Se yeast supplementation on the plasma P4 concentrations (ng/ $\mathrm{mL}$ ) of all $\mathrm{CL}$ that formed during the first 100 postpartum days (A), CL that developed after the third ovulation with estrus (B), $C L$ that developed after ovulation with estrus between 60 to 80 days after calving (C). Blood sampling from the jugular vein was carried out in the morning every two days. Plasma P4 concentrations were measured using an enzyme immunoassay kit after diethylether extraction. All assays were performed in duplicate. Data are presented as mean \pm standard error of the mean values (-Se: $n=43,+$ Se: $n=45)$ in A, (-Se: $n=11,+$ Se: $n=11)$ in B, (-Se: $n=8$, + Se: $n=12$ ) in C. Significance was defined as a $p$ value of $<0.05$. 
the culture medium [26] and that the Se supplementation of non-pregnant and non-lactating cows increased their plasma P4 concentration during the estrous cycle [27]. In the present study, it was clearly demonstrated that pre- and postpartum Se supplementation to the diet increased the postpartum plasma $\mathrm{P} 4$ concentration of dams.

The reproductive performance of dairy cows is affected by energy intake and CP intake in the postpartum period $[5,6,20]$, as well as their milk production [28], as mentioned above. A negative energy balance, the oversupply of $\mathrm{CP}$, and high milk production delay the recovery of ovary function after calving, resulting in a low conception rate. So, in this experiment, the Se treatment group and control groups were subjected to identical nutritional conditions except for Se level (including milk production) to allow us to investigate the effects of Se on the plasma P4 levels of cows after calving. The mean BW change, and DM, TDN, and CP intake values of the two groups did not differ between the two treatments, nor did their milk production or the biochemical properties of their blood plasma (except for the plasma $\mathrm{LDH}$ activity on day 0 when there is no $\mathrm{CL}$ ). While the plasma Se concentrations of the Se-yeast supplemented cows were significantly greater than those of the ordinary yeastsupplemented animals (control) at and after calving. The plasma Se concentrations of the Se-treated group were in sufficient level (>70 ppb) [21]; however, those of the control group remained considerably low throughout the experimental period. The gradual increase in the mean plasma Se concentration after calving regardless of treatment is a general tendency, which is caused by increased diet intake (in particular, concentrates usually contain a relatively large amount of Se than grasses). These results indicated that nutritional conditions except for Se were not different between the two groups, so the effect of $\mathrm{Se}$ on the plasma P4 level was estimated under the same nutritional conditions.

The early recovery of postpartum ovary function is necessary to increase the conception rate of cows [29]. In the present study, the greater average concentration of postpartum plasma $\mathrm{P} 4$ in Se-supplemented cows suggested the functional CL developed earlier after calving in the cows subjected to pre- and postpartum Se supplementation than in the control (Figure 4). Selenium supplementation realized early recovery of postpartum ovary function and more promoted the formation of functional CL during the optical period for first AI (Figure 5C). Selenium is known to improve the reproductive performance of various animals [30,31]; however, its target tissue has not been identified. A positive correlation between the postpartum plasma $\mathrm{P} 4$ concentrations of cows and their conception rate has been reported [3], so it is suggested that the activation of luteal function by Se feeding leads to improved reproduction performance in cows. The mean plasma P4 AUC value for all CL (Figure 5A) included the data for $\mathrm{CL}$ formed in various physiological conditions, for example, the short luteal phase after the first ovulation (which had a small AUC due to physiological reasons), so no statistical difference was detected between the groups. While Figure 5B (CL formed after the third ovulation) and Figure 5C (CL formed after ovulation between 60 to 80 days after calving) did display statistically significant inter-group differences.

The generation of peroxides is presumed to induce sound $\mathrm{CL}$ to undergo luteolysis [32]. $\mathrm{H}_{2} \mathrm{O}_{2}$ or lipid peroxide have been found to accumulate in the CL during luteal regression $[33,34]$, while antioxidant vitamins have been reported to be effective against reactive oxygen species in cultured rat luteal cells [35]. Our previous in vitro investigation using bovine luteal cells also showed that the addition of Se (antioxidant substance) to luteal cells decreased their intracellular lipid peroxide levels [26]. Thus, it is possible that the detoxifying effect of Se on peroxide production contributes to the maintenance of CL function. In the present study, no biopsies of CL or assessments of their lipid peroxide content were carried out because such sampling would have affected the functions of the CL as well as the $\mathrm{P} 4$ production data. It is likely that functional CL is a tissue which inevitably accumulates peroxide due to their synthesis of $\mathrm{P} 4$, and hence, requires antioxidants to maintain their function. Our previous in vitro experiments also showed that the addition of luteinizing hormone ( $\mathrm{LH})$ to the luteal cultures stimulated P4 synthesis and simultaneously increased the intracellular lipid peroxide concentrations of the cells [26]. Selenium is known to be an essential component of antioxidant enzymes, as mentioned above. Thus, the antioxidant effects of Se can explain the increased $\mathrm{P} 4$ production observed in the present study. Harrison et al [11] reported that significant Sedependent GPX activity was detected in luteal tissues, and Zagrodzki and Ratajczak [36] demonstrated a strong positive correlation between GPX3 activity and P4 levels in humans. These reports support the idea that Se has a positive effect on CL function.

Other non-antioxidant-based mechanisms likely explain the increased plasma P4 concentrations induced by Se. Behne et al [25] reported that in mice Se is preferentially incorporated into the pituitary gland and brain, as was found for CL. If the same situation occurs in ruminants, Se probably plays an important role in these organs. Another study is needed to clarify the effects of Se on the pituitary gland or hypothalamus, which are located upstream in the physiological signaling pathways involved in the regulation of ovary function. For example, Se might increase the pulsatile $\mathrm{LH}$ or accelerate follicle-stimulating hormone secretion. Basini et al [37] proposed another possible effect of Se on bovine follicles. Selenium was found to directly stimulate estradiol production in bovine granulosa cells as well the proliferation of these cells by the preventing nitric oxide production. Therefore, Se might accelerate follicle maturation leading to early ovulation. The suppression of P4 catabolism by $\mathrm{Se}$ is another possible explanation for the increased P4 level observed in the present study. Lemley et al [38] reported 
that feed composition (a high cornstarch diet or high fiber diet) affected P4 clearance, and Sangsritavong et al [39] demonstrated that higher feed intake increased liver blood flow and steroid metabolism; however, neither feed intake nor the composition of the feed differed between the two treatment groups in this study. Steroid hormones are broken down in the liver and excreted via bile; however, Se status probably does not affect the composition (including the cholesterol) of bile [40]. We could not carry out a $\mathrm{P} 4$ infusion experiment to observe $\mathrm{P} 4$ clearance in this study, so it was unclear whether the increased plasma P4 concentration observed after Se supplementation was due to decreased catabolism of $\mathrm{P} 4$ in the liver. However, our previous in vitro experiment showed that Se had a direct effect on luteal cells [26]. Thus, we consider that an identified Se function (antioxidant effect) can reasonably explain the result (elevated plasma P4 concentration after Se supplementation) of the present study without other assumptions regarding unknown Se functions.

As shown in Figure 3, cows that were not supplemented with Se had too little of the mineral in the pre- and postpartum periods. Early embryonic mortality reported in Se-deficient animals [41] might have been caused by depressed luteal function. The results of the present study indicate the possibility that Se supply to cows during the pre- and postpartum periods leads to the early recovery of luteal function and an increased conception rate. Although Se supplementation cannot resolve all reproduction problems, it can contribute to improving the worsening fertility of dairy cows. This information could be useful for animal farmers. Moreover, $\mathrm{CL}$ is commonly required to maintain pregnancy in mammals, so our results might be useful for aiding the reproduction of other mammals, including humans.

\section{CONFLICT OF INTEREST}

We certify that there is no conflict of interest with any financial organization regarding the material discussed in the manuscript.

\section{ACKNOWLEDGMENTS}

This work was supported by grants from the Ministry of Agriculture, Forestry and Fisheries of Japan. The authors thank Dr. T. Yasui (Bussan-Biotech Co. Ltd., Tokyo) for providing seleniumrich yeast. We would also like to thank Dr. O. Sasaki (Institute of Livestock and Grassland Science NARO) for his statistical advice. All helps from the staff of the Ruminant and Field Management Section of Hokkaido Agriculture Research Center NARO for their assistance with the animal handling and care are acknowledged.

\section{REFERENCES}

1. Pursley JR, Martins JP. Impact of circulating concentrations of progesterone and antral age of the ovulatory follicle on fertility of high-producing lactating dairy cows. Reprod Fertil Dev 2011; 24:267-71.

2. Inskeep EK. Preovulatory, and postmaternal recognition effects of concentrations of progesterone on embryonic survival in the cow. J Anim Sci 2004;82E-Suppl:E24-39.

3. Staples CR, Burke JM, Thatcher WW. Influence of supplemental fats on reproductive tissues and performance of lactating cows. J Dairy Sci 1998;81:856-71.

4. Britt JH, Show DW, Washbum SP, Hedgpeth VS. Endogenous progesterone during luteal phase before insemination influences embryo recovery in lactating Holstein cows. J Anim Sci 1996;74 (Supp. 1):225.

5. Spicer LJ, Vernon RK, Tucker WB, et al. Effects of inert fat on energy balance, plasma concentrations of hormones, and reproduction in dairy cows. J Dairy Sci 1993;76:2664-73.

6. Son JR, Grant J, Larson LL. Effects of tallow and escape protein on lactation and reproductive performance of dairy cows. J Dairy Sci 1996;79:822-30.

7. Petit HV, Twagiramungu $\mathrm{H}$. Conception rate and reproductive function of dairy cows fed different fat sources. Theriogenology 2006;66:1316-24.

8. Thacher WW, Staples CR, Danet-Desnoyyers G, Oldick B, Schmit EP. Embryo health and mortality in sheep and cattle. J Anim Sci 1994;72(Supp. 3):16-30.

9. Kawashima C, Nagashima S, Sawada K, et al. Effect of $\beta$-carotene supply during close-up dry period on the onset of first postpartum luteal activity in dairy cows. Reprod Domest Anim 2010;45:e282-7.

10. Arellano-Rodriguez G, Meza-Herrera CA, Rodriguez-Martinez $\mathrm{R}$, et al. Short-term intake of beta-carotene-supplemented diets enhances ovarian function and progesterone synthesis in goats. J Anim Physiol An N 2009;93:710-5.

11. Harrison JH, Conrad HR. Selenium content and glutathione peroxidase activity in tissues of the dairy cow after short-term feeding. J Dairy Sci 1984;67:2464-70.

12. Arechiga CF, Ortiz O, Hansen PJ. Effect of prepartum injection of vitamin $\mathrm{E}$ and selenium on postpartum reproductive function of dairy cattle. Theriogenology 1994;41:1251-8.

13. Kommisrud E, Osterảs O, Vatn T. Blood selenium associated with health and fertility in Norwegian dairy herds. Acta Vet. Scand 2005; 46:229-40.

14. Molina MM, Karami H, Mikaeili E. Effect of selenium and vitamin E supplementation during the late pregnancy on reproductive indices and milk production in heifers. Anim Reprod Sci 2009; 114:109-14.

15. Allan CB, G. Lacourciere GM, Stadtman TC. Responsiveness of selenoproteins to dietary selenium. Ann Rev Nutr 1999;19:1-16.

16. Committee on Nutrient Requirements of Dairy cattle, National Research Council. Nutrient requirements of dairy cattle, 7th rev. ed. Washington, DC: National Acadmic Press; 2001.

17. National Agriculture and Food Research Organization. In: Standard table of feed composition in Japan. Japan: Japan Livestock Industry Association; 2009. p. 14-15. 
18. Van Soest PJ. Collaborative study of acid detergent fiber and lignin. J AOAC INT 1973;56:781-4.

19. SAS Institute. version 9.2. USA: Cary NC; 2008.

20. Furguson JD, Blanchard T, Galligan DT, Hoshall DC, Chalupa W. Infertility in dairy cattle fed a high percentage of protein degradable in the rumen. JAVMA 1988;192:659-62.

21. Puls R. In: Veterinary trace mineral deficiency and toxicity information. Ottawa: Agriculture Canada; 1981. p. 75-88.

22. Young FM, Luderer WB, Rodgers RJ. The antioxidant beta-carotene prevents covalent cross-linking between cholesterol side-chain cleavage cytochrome P450 and its electron donor, adrenodoxin, in bovine luteal cells. Mol. Cell Endocrinol 1995;109:113-8.

23. Rotruck JT, Pope JT, Ganther HE, et al. Selenium: Biochemical role as a component of glutathione peroxidase. Science 1973;179: 588-90.

24. Ursini F, Maiorino M, Gregolin C. The selenoenzyme: phospholipid hydropperoxide glutathione peroxidase. Biochim Biophy Acta 1985;839:62-70.

25. Behne D, Hilmert H, Scheid S, Gessner H, Elger W. Evidence for specific selenium target tissues and new biologically important selenoproteins. Biochim Biophy Acta 1988;966:12-21.

26. Kamada H, Ikumo H. Effect of selenium on cultured bovine luteal cells. Anim Reprod Sci 1997;46:203-11.

27. Kamada H, Hodate K. Effect of dietary selenium supplementation on the plasma progesterone concentration in cows. J Vet Med Sci 1998;60:133-5.

28. Cutullic E, Delaby L, Gallard Y, Disenhaus C. Towards a better understanding of the respective effects of milk yield and body condition dynamics on reproduction in Holstein dairy cows. Animal 2012;6:476-87.

29. Darwash AO, Lamming GE, Wooliams JA. The phenotypic association between the interval to post-partum ovulation and traditional measures of fertility in dairy cattle. Anim Sci 1997;65: 9-16.

30. Hartley WJ. Selenium and ewe fertility. In: Proceeding of the New Zealand Society of Animal Production. New Zealand: 1963. p. 20-7.
31. Harrison JH, Hancock DD, Conrad HR. Vitamin E and selenium for reproduction of the dairy cow. J Dairy Sci 1984;67:123-32.

32. Kodaman PH, Aten RF, Behrman HR. Lipid hydroproxides evoke antigonadotropic and antisteroidogenic activity in rat luteal cells. Endocrinology 1994;135:2723-30.

33. Riley JCM. Behrman HR. In vivo generation of hydrogen peroxide in the rat corpus luteum during luteolysis. Endocrinology 1991; 128:1749-53.

34. Hesla JS, Miyazaki T, Dasko LM, Wallach EE, Dharmarajan, AM. Superoxide dismutase activity, lipid peroxide production and corpus luteum steroidgenesis during natural luteolysis and regression induced by oestradiol deprivation of the ovary in pseudopregnant rabbits. J Reprod Fertil 1992;95:915-24.

35. Carlson JC, Sawada M, Boone DL, Stauffer JM. Stimulation of progesterone secretion in dispersed cells of rat corpora lutea by antioxidants. Steroids 1995;60: 272-6.

36. Zagrodzki Ratajczak R. Selenium status, sex hormones, and thyroid function in young woman. J Trace Elem Med Bio 2008;22:296304.

37. Basini G, Tamanini C. Selenium stimulates estradiol production in bovine granulosa cells: possible involvement of nitric oxide. Domest Anim Endcrinol 2000;18:1-17.

38. Lemley CO, Vonnahme KA, Tager LR, Krause KM, Wilson ME. Diet-induced alterations in hepatic P4 catabolic enzyme activity and P4 clearance rate in lactating dairy cows. J Endcrinol 2010; 205:233-41.

39. Sangsritavong S, Combs DK, Sartori R, Armentano LE, Wiltbank MC. High feed intake increases liver blood flow and metabolism of progesterone and estradiol-17beta in dairy cattle. J Dairy Sci 2002;85:2831-41.

40. Sakuma Y, Sasaki J, Futami A, et al. Changes in the components of biliary and plasma lipids in selenium deficient rats. Chem Phys Lipids 2007;148:70-6.

41. Andrew ED, Hartley WJ, Grant AB. Selenium-responsive disease of animals in New Zealand. New Zeal Vet J 1968;16:3-7. 